\title{
Preliminary study on the anti-inflammatory and antioxidant activities of the leave extract of Hyptis fruticosa Salzm. ex Benth., Lamiaceae
}

\author{
Alexandre M. Andrade, ${ }^{1}$ Juliana P. R. Oliveira, ${ }^{1}$ André L. L. M. Santos, ${ }^{2}$ Clóvis R. P. Franco, ${ }^{3}$ \\ Ângelo R. Antoniolli, ${ }^{3}$ Charles $S$. Estevam, ${ }^{2}$ Sara M. Thomazzi, ${ }^{, 1}$
}

${ }^{1}$ Laboratório de Farmacologia da Inflamação, Departamento de Fisiologia, Centro de Ciências Biológicas e da Saúde, Universidade Federal de Sergipe, Av. Marechal Rondon s/n, 49100-000 São Cristóvão-SE, Brasil, ${ }^{2}$ Laboratório de Bioquímica, Departamento de Fisiologia, Centro de Ciências Biológicas e da Saúde, Universidade Federal de Sergipe, Av. Marechal Rondon s/n, 49100-000 São Cristóvão-SE, Brasil,

${ }^{3}$ Laboratório de Farmacologia da Dor, Departamento de Fisiologia, Centro de Ciências Biológicas e da Saúde, Universidade Federal de Sergipe, Av. Marechal Rondon s/n, 49100-000 São Cristóvão-SE, Brasil.

\begin{abstract}
RESUMO: "Avaliação das atividades anti-inflamatória e antioxidante do extrato etanólico das folhas da Hyptis fruticosa Salzm. ex Benth., Lamiaceae". Várias espécies do gênero Hyptis são utilizadas na medicina popular para tratar processos inflamatórios. Para avaliar as ações anti-inflamatória e antioxidante da Hyptis fruticosa Salzm. ex Benth., Lamiaceae, utilizou-se extrato etanólico (EE) das folhas desta planta e suas partições $n$ - $\mathrm{C}_{6} \mathrm{H}_{14}, \mathrm{CHCl}_{3}$, AcOEt e $\mathrm{MeOH} / \mathrm{H}_{2} \mathrm{O}$. O tratamento oral com o EE das folhas da H. fruticosa $(100,200$ e 400 $\mathrm{mg} / \mathrm{kg}$ ) ou suas partições $n-\mathrm{C}_{6} \mathrm{H}_{14}$, AcOEt e $\mathrm{MeOH} / \mathrm{H}_{2} \mathrm{O}(50,100$ e $200 \mathrm{mg} / \mathrm{kg})$ apresentou atividade inibitória sobre a formação de edema e migração leucocitária para a cavidade peritoneal induzidas pela carragenina em ratos $(p<0,05)$. Entretanto, a partição $\mathrm{CHCl}_{3}$ não causou nenhum efeito sobre a formação de edema e migração de células peritoneais. $O$ EE bruto e a partição AcOEt apresentaram alto potencial antioxidante (IC50 $=35,00 \pm 1,01$ e $36,67 \pm 2,65 \mu \mathrm{g} / \mathrm{mL}$ DPPH, respectivamente), similar ao composto referência (IC50 = $16,67 \pm 1,21 \mu \mathrm{g} / \mathrm{mL}$ ). Em conclusão, demonstrou-se que a $H$. fruticosa apresenta atividades anti-inflamatória e antioxidante.
\end{abstract}

Unitermos: Anti-inflamatória, antioxidante, edema, Hyptis fruticosa, Lamiaceae, migração celular.

\begin{abstract}
Various species of Hyptis are used in folk medicine as anti-inflammatory. In order to evaluate the actions of Hyptis fruticosa Salzm. ex Benth., Lamiaceae, studies were performed on anti-inflammatory and antioxidant activities. The ethanol extract (EE) of $\mathrm{H}$. fruticosa leaves and its $n-\mathrm{C}_{6} \mathrm{H}_{14}, \mathrm{CHCl}_{3}$, EtOAc, and $\mathrm{MeOH} / \mathrm{H}_{2} \mathrm{O}$ partitions were used in the following experiments. Oral treatment with the EE of $H$. fruticosa leaves $(100,200$, and $400 \mathrm{mg} / \mathrm{kg}$ ) or its $n-\mathrm{C}_{6} \mathrm{H}_{14}$, EtOAc, and $\mathrm{MeOH} / \mathrm{H}_{2} \mathrm{O}$ partitions $(50,100$, and $200 \mathrm{mg} / \mathrm{kg}$ ) elicited inhibitory activity $(p<0.05)$ on carrageenan-induced oedema formation and leukocyte migration into the peritoneal cavity in rats. However, the $\mathrm{CHCl}_{3}$ partition did not show any inhibitory effect on paw oedema and peritonitis experimental models. The EE and EtOAc partition present the highest antioxidant potential (IC50 $=35.00 \pm 1.01$ and $36.67 \pm 2.65 \mu \mathrm{g}$ / $\mathrm{mL}$ DPPH, respectively), similar to the reference compound (IC50 $=16.67 \pm 1.21 \mu \mathrm{g} / \mathrm{mL}$ ). In conclusion, $H$. fruticosa shows anti-inflammatory and antioxidant activities.
\end{abstract}

Keywords: Anti-inflammatory, antioxidant, cellular migration, Hyptis fruticosa, Lamiaceae, oedema.

\section{INTRODUCTION}

The use of natural products with therapeutic properties is as ancient as human civilization (Esquenazi et al., 2002). Most people living in developing countries are almost completely dependent on traditional medical practices for their primary health care needs and higher plants are known to be the main source for drug therapy 
in traditional medicine (Calixto, 2005).

The genus Hyptis contains about 400 species distributed mainly at the central states of Brazil (Harley, 1988). Various species are used in folk medicine as anti-inflammatory, antinociceptive, anticonvulsant, and antiulcerogenic (Barbosa \& Ramos, 1992; Akah \& Nwambie, 1993; Kuhnt et al., 1995; Bispo et al., 2001). The aqueous extract and volatile oil of Hyptis pectinata showed antiedematogenic and antinociceptive activities in animal models (Bispo et al., 2001; Arrigoni-Blank et al., 2008).

Hyptis fruticosa Salzm. ex Benth., Lamiaceae, popularly known as "alecrim-de-tabuleiro" is an aromatic sub-bush plant which grows up to $1.5 \mathrm{~m}$ found on the Brazilian northeast coast. Previous studies have demonstrated that the essential oil from $H$. fruticosa presents antinociceptive peripheral and hypotensive activities (Menezes et al., 2007; Santos et al., 2007). Silva et al. (2006) have demonstrated that the aqueous extract from $H$. fruticosa presents antinociceptive activity.

Although $H$. fruticosa is popularly described as an anti-inflammatory, the potential in vivo antiinflammatory activity of the extracts from $H$. fruticosa leaves has not been investigated. The goal of the present study was to evaluate the anti-inflammatory and antioxidant effects of the crude ethanol extract (EE) and various solvent partitions from Hyptis fruticosa leaves.

\section{MATERIALS AND METHODS}

Plant material, extraction of Hyptis fruticosa leaves and partitioning

Aerial parts of Hyptis fruticosa Salzm. ex Benth., Lamiaceae, were collected in the municipality of São Cristóvão, Sergipe State, Brazil, in January 2007 (11 $\left.1^{\circ} 01^{\prime} 47^{\prime \prime} \mathrm{S}, 37^{\circ} 20^{\prime} 64^{\prime \prime} \mathrm{W}\right)$. The plant was authenticated by Professor Clovis R. Franco, Department of Biology, Federal University of Sergipe, and a voucher specimen deposited in the Federal University of Sergipe Herbarium (voucher number ASE 10.922). The dried leaves (1300 g) of $H$. fruticosa at $40{ }^{\circ} \mathrm{C}$ in a forced air oven for $48 \mathrm{~h}$ were powdered and submitted to extraction at ambient temperature $\left(25-28{ }^{\circ} \mathrm{C}\right)$ with $90 \%$ ethanol $(8 \mathrm{~L})$ for five days. After filtration, the solvent was removed with rotary evaporator under reduced pressure $\left(45^{\circ} \mathrm{C}\right)$. The percentage of yield of the leaves EE was $15.0 \%(195.0$ g). The components of the crude EE were partitioned in a Soxhlet apparatus sequentially with solvents of increasing polarity. The crude EE (150.0 g) was suspended in a mixture of water:methanol $(3: 2, \mathrm{v} / \mathrm{v})$ and extracted with hexane $\left(n-\mathrm{C}_{6} \mathrm{H}_{14}, 4 \times 250 \mathrm{~mL}\right)$, chloroform $\left(\mathrm{CHCl}_{3}, 4 \times 250\right.$ $\mathrm{mL}$ ), and ethyl acetate (EtOAc, 4x $250 \mathrm{~mL}$ ), successively. After the solvent removal under reduced pressure on a rotatory evaporator, hexane $(9.4 \mathrm{~g})$, chloroform $(26.2 \mathrm{~g})$, ethyl acetate $(38.3 \mathrm{~g})$, and hydromethanolic $\left(\mathrm{MeOH} / \mathrm{H}_{2} \mathrm{O}\right.$,
$45.3 \mathrm{~g}$ ) partitions were obtained.

\section{Phytochemical screening}

The methods of Harbone (1984) were used to screen the EE of $H$. fruticosa leaves used in this study for its chemical constituents.

\section{Chemicals and drugs}

The following chemicals and drugs were used: acetylsalicylic acid (ASA), carrageenan, dexamethasone, 2,2-diphenyl-1-picrylhydrazyl (DPPH), and (-)-epigallocatechin from Sigma Chemical Co. (St. Louis, MO, USA). Solvents from Vetec (Rio de Janeiro, RJ, Brazil). All substances used were dissolved in $0.2 \%$ Tween 80 in $0.9 \% \mathrm{NaCl}$ solution, with the exceptions of DPPH and (-)-epigallocatechin that were dissolved in methanol. The final concentration of Tween 80 did not exceed $0.2 \%$ and did not cause any effect per se.

\section{Animals}

Wistar rats (120-180 g) of both sexes were obtained from the Central Biotery of the Federal University of Sergipe (São Cristóvão, Brazil). Animals were maintained in plastic boxes at controlled room temperature $\left(21 \pm 2{ }^{\circ} \mathrm{C}\right)$ with free access to food and water, under a 12:12 h light/dark cycle. All the experimental procedures were carried out during the light period of the day ( 8 a.m. to 5 p.m.) and complied with the guidelines on animal care of the Federal University of Sergipe Ethics Committee for Animal Use in Research (CEPA/ UFS 25/07).

\section{Measurement of paw oedema}

The anti-inflammatory activity was evaluated using the paw oedema model induced by $1 \%$ carrageenan, administrated at volume of $0.1 \mathrm{~mL} / \mathrm{animal}$ into the subplantar region of the rat right hindpaw (Winter et al., 1962). Paw oedema was measured plethysmographically (model 7150, Ugo Basile, Varese, Italy), at the time 0 and the intervals of $1,2,3$, and $4 \mathrm{~h}$ immediately after the subplantar injection of carrageenan.

The EE of H. fruticosa leaves (100-400 mg/kg), its partitions $(50-200 \mathrm{mg} / \mathrm{kg}$ ), acetylsalicylic acid (ASA, $300 \mathrm{mg} / \mathrm{kg})$, or vehicle $(5 \mathrm{~mL} / \mathrm{kg})$ were administrated orally (p.o.) $1 \mathrm{~h}$ before the oedematogenic agent $(n=6 /$ group). Data obtained for the various groups were reported as means \pm s.e.m. and expressed in $\mathrm{mL}$. The percentage inhibition in oedema experiment was calculated based on the area under the time-course curves $\left(\mathrm{AUC}_{0-4 \mathrm{~h}}\right)$ using trapezoidal rule. 


\section{Leukocyte migration into the peritoneal cavity}

The leukocyte migration was induced by intraperitoneal (i.p.) injection of carrageenan $(500 \mu \mathrm{g} /$ cavity, $500 \mu \mathrm{L}$ ) into the peritoneal cavity of rats $1 \mathrm{~h}$ after administration of the EE of $H$. fruticosa leaves (100-400 $\mathrm{mg} / \mathrm{kg}$, p.o., $\mathrm{n}=6)$, its partitions $(50-200 \mathrm{mg} / \mathrm{kg}$, p.o., $\mathrm{n}=6$ ), dexamethasone (2 $\mathrm{mg} / \mathrm{kg}$, s.c., $\mathrm{n}=6)$, or vehicle as previously described by Thomazzi et al. (2010). The animals were anesthetized with sodium pentobarbital (50 $\mathrm{mg} / \mathrm{kg}$, i.p.) and were euthanized by cervical dislocation $4 \mathrm{~h}$ after carrageenan injection. Shortly after, saline containing EDTA ( $1 \mathrm{mM}$, i.p., $10 \mathrm{~mL})$ was injected into the peritoneal cavity. The total cells were counted in a Neubauer chamber, under optic microscopy. The results were expressed as the number of leukocytes $/ \mathrm{mL}$. The inhibition percentage of the leukocyte migration was calculated according the equation: $(1-T / C) \times 100$, where $T$ and $C$ represent the treated and control group leukocyte counts, respectively.

\section{Quantitative assay of antioxidant activity}

The quantitative analysis of antioxidant activity was based on the method described by Brand-Williams et al. (1995), with minor modifications. The scavenging of 2,2-diphenyl-1-picrylhydrazyl (DPPH) radical was followed by monitoring the decrease in absorbance at 515 $\mathrm{nm}$, which occurred due to reduction by the antioxidant.

The calibration curve was established by preparing dilutions of a DPPH radical stock solution (40 $\mu \mathrm{g} / \mathrm{mL})$ to obtain final concentrations of $1,5,10,15,20$, 25,30 , and $35 \mu \mathrm{g} / \mathrm{mL}$. The absorbance of each standard concentration was then monitored in a spectrophotometer (UV BEL Photonics 1105) at $515 \mathrm{~nm}$. The measures were carried out in triplicate with intervals of $1 \mathrm{~min}$. The equation of the concentration $\mathrm{x}$ absorbance calibration curve for the DPPH radical was $C=110.547-0.02804 \mathrm{~A}$, where $C$ is the concentration of the DPPH radical in medium, $\mathrm{A}$ is the absorbance at $515 \mathrm{~nm}$. The correlation coefficient was $\mathrm{r}=0.9983$.

Solutions containing $500 \mu \mathrm{g} / \mathrm{mL}$ of Hyptis fruticosa leaves EE and its partitions were prepared in methanol, and diluted in concentrations of $1,5,10,15$, $20,25,30$, and $35 \mu \mathrm{g} / \mathrm{mL}$. The disappearance of DPPH radical was monitored by the decrease in absorbance at $515 \mathrm{~nm}$, which was recorded after $0,1,5$, and $10 \mathrm{~min}$, and subsequently every $10 \mathrm{~min}$ up to $1 \mathrm{~h}$. The negative control was pure methanol used for dissolving the samples, while the positive control was the (-)-epigallocatechin dissolved in methanol in concentrations of $1,5,10,15,20,25,30$, and $35 \mu \mathrm{g} / \mathrm{mL}$. The mixture of methanol and sample was used as blank.

The concentration of the DPPH radical in the reaction mixture was calculated based on calibration curve, where [DPPH] is expressed in $\mu \mathrm{g} / \mathrm{mL}$. The percentage of remaining DPPH $\left(\% \mathrm{DPPH}_{\mathrm{REM}}\right)$ was calculated as follows: $\% \mathrm{DPPH}_{\mathrm{REM}}=[\mathrm{DPPH}]_{T} /[\mathrm{DPPH}]_{T 0} \times 100$, where $T$ is the time when absorbance was determined (1-60 min) and $\mathrm{T}_{0}$ is the time zero. The amount of antioxidant necessary to decrease the initial concentration of DPPH radical by $50 \%$ (IC50) was calculated by plotting the $\% \mathrm{DPPH}_{\mathrm{REM}}$ at time of $50 \mathrm{~min}(25 \mu \mathrm{g} / \mathrm{mL})$. The results were expressed as $\mu \mathrm{g}$ antioxidant $/ \mathrm{mL} \mathrm{DPPH} \pm$ standard deviation.

\section{Statistical analysis}

The results of anti-inflammatory activity are presented as the mean \pm s.e.m. of $n$ animals per group. The values of antioxidant effect are demonstrated as the mean \pm standard deviation (triplicate). Statistical evaluation of the data was performed using one-way analysis of variance (ANOVA) followed by Tukey's test. $p$ values less than 0.05 were considered significant.

\section{RESULTS}

\section{Phytochemical screening}

Phytochemical screening of the EE of $\mathrm{H}$. fruticosa leaves showed that the crude EE contain large amounts of chalcones, flavones, flavonols, phenols, saponins, steroids, tannins, triterpenes, and xanthones. The $n-\mathrm{C}_{6} \mathrm{H}_{14}$ partition exhibited large amounts of steroids and triterpenes, and the $\mathrm{CHCl}_{3}$ partition exhibited large amounts of chalcones and triterpenes. Furthermore, the EtOAc and $\mathrm{MeOH} / \mathrm{H}_{2} \mathrm{O}$ partitions presented significant quantities of flavones, flavonols, phenols, saponins, tannins, and xanthones.

\section{Carrageenan-induced paw oedema in rats}

The anti-inflammatory effect of the EE of $H$. fruticosa leaves $(100-400 \mathrm{mg} / \mathrm{kg})$ was evaluated by the paw oedema model ( $n=6 /$ group). As observed in Figure 1, the single oral treatment of rats with the EE of $H$. fruticosa leaves at 100, 200, and $400 \mathrm{mg} / \mathrm{kg}$ was capable of reducing $(p<0.05)$ the oedema formation induced by carrageenan $(1 \%, 100 \mu \mathrm{L} / \mathrm{paw})$, an effect observed at $3 \mathrm{~h}$ after the administration of this phlogistic agent. Additionally, the EE at 100 and $400 \mathrm{mg} / \mathrm{kg}$ (p.o., $1 \mathrm{~h}$ beforehand) reduced $(p<0.05)$ the oedema formation induced by carrageenan at 2 and $4 \mathrm{~h}$. Likewise, ASA (300 mg/kg, p.o., $1 \mathrm{~h}$ beforehand, $\mathrm{n}=6$ ) significantly inhibited $(p<0.001)$ the oedematogenic response evoked by carrageenan in rats, at 2, 3, and $4 \mathrm{~h}$ (Figure 1).

In the assay with the EE the mean AUC found in carrageenan-treated rats was $2.97 \pm 0.20 \mathrm{~mL} \times \mathrm{h}(\mathrm{n}=6)$. Based on AUC values, the EE at 100, 200, and $400 \mathrm{mg} / \mathrm{kg}$ caused $33.3,27.6$, and $30.6 \%(p<0.05)$ of inhibition on oedema response, respectively ( $n=6 /$ group). ASA at 300 $\mathrm{mg} / \mathrm{kg}(\mathrm{n}=6)$ caused an inhibition of $43.1 \%(p<0.001)$. 
Table 1 shows that the $n-\mathrm{C}_{6} \mathrm{H}_{14}$ and $\mathrm{MeOH} / \mathrm{H}_{2} \mathrm{O}$ partitions of $H$. fruticosa $\mathrm{EE}$ at 50,100 , and $200 \mathrm{mg} / \mathrm{kg}$ (p.o., $1 \mathrm{~h}$ beforehand) were capable of reducing $(p<0.01)$ the oedema formation induced by carrageenan $(1 \%, 100$ $\mu \mathrm{L} /$ paw). The EtOAc partition of $H$. fruticosa $\mathrm{EE}$ was capable of reducing $(p<0.001)$ the paw oedema formation at $50 \mathrm{mg} / \mathrm{kg}$ (p.o., $1 \mathrm{~h}$ beforehand). However, the $\mathrm{CHCl}_{3}$ partition $(50,100$, and $200 \mathrm{mg} / \mathrm{kg}$, p.o., $1 \mathrm{~h}$ beforehand) presented no activity on oedema formation induced by carrageenan. The partitions of the EE reduced the oedema formation induced by carrageenan at 2 and $4 \mathrm{~h}$ (data not show).

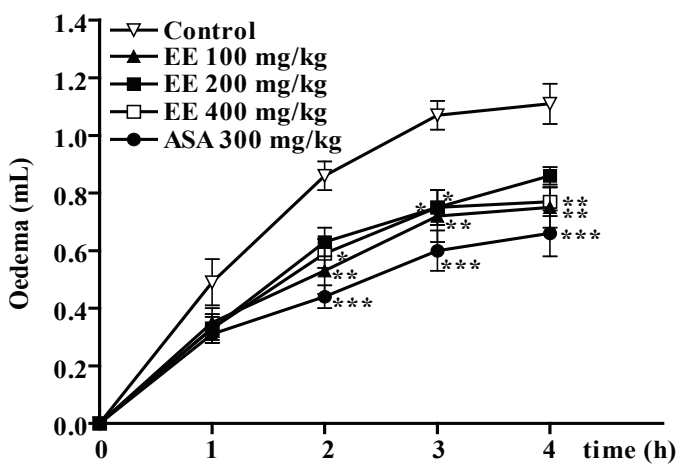

Figure 1. Effect of Hyptis fruticosa leaves EE on paw oedema. Rats were pre-treated (p.o., $\mathrm{n}=6 /$ group) with vehicle (control), acetylsalicylic acid (ASA, $300 \mathrm{mg} / \mathrm{kg})$, or EE (100-400 mg/kg) $1 \mathrm{~h}$ before carrageenan $(1 \%, 100 \mu \mathrm{L})$. Each value represents the mean \pm s.e.m. $* p<0.05, * * p<0.01$, and $* * * p<0.001$, in relation to control group. ANOVA followed by Tukey's test.

\section{Carrageenan-induced peritonitis in rats}

Carrageenan $(500 \mu \mathrm{g} /$ cavity) induced leukocyte migration into the peritoneal cavity $4 \mathrm{~h}$ after stimulus. Figure 2 shows the inhibitory effect of the EE of $H$. fruticosa leaves $(46.7,33.1$, and $47.8 \%$ at 100,200 , and $400 \mathrm{mg} / \mathrm{kg}$, respectively, $p<0.05$ ) on the carrageenaninduced response. The control drug dexamethasone $(2$ $\mathrm{mg} / \mathrm{kg}$, s.c., $1 \mathrm{~h}$ beforehand) inhibited $(62.5 \%, p<0.001)$ the carrageenan-induced leukocyte migration into the peritoneal cavity.

Table 2 shows that the $n-\mathrm{C}_{6} \mathrm{H}_{14}$, EtOAc, and $\mathrm{MeOH} / \mathrm{H}_{2} \mathrm{O}$ partitions of $H$. fruticosa $\mathrm{EE}$ at 50, 100, and $200 \mathrm{mg} / \mathrm{kg}$ (p.o., $1 \mathrm{~h}$ beforehand) were capable of reducing $(p<0.01)$ the carrageenan-induced leukocyte migration into the peritoneal cavity $(500 \mu \mathrm{g} /$ cavity, $4 \mathrm{~h}$ after). However, the $\mathrm{CHCl}_{3}$ partition $(50,100$, and 200 $\mathrm{mg} / \mathrm{kg}$, p.o., $1 \mathrm{~h}$ beforehand) presented no activity on leukocyte migration into the peritoneal cavity induced by carrageenan.

\section{Antioxidant activity}

According to the IC50 values, the antioxidant concentration needed to decrease by $50 \%$ the initial concentration of DPPH radical is the highest for the $n-\mathrm{C}_{6} \mathrm{H}_{14}, \mathrm{CHCl}_{3}$, and $\mathrm{MeOH} / \mathrm{H}_{2} \mathrm{O}$ partitions, as compared with the reference compound (-)-epigallocatechin (triplicate, $p<0.05$, Table 3 ). The IC50 values for EE and EtOAc partition (triplicate) were similar to IC50 value of the reference compound.

Table 1. Inhibitory effects of the partitions of Hyptis fruticosa leaves EE on rat paw oedema induced by carrageenan based on the area under the curves (AUC) after $4 \mathrm{~h}$.

\begin{tabular}{ccccccccc}
\hline & $\mathrm{MeOH} / \mathrm{H}_{2} \mathrm{O}$ & \multicolumn{2}{c}{ EtOAc } & \multicolumn{2}{c}{-C $_{6} \mathrm{H}_{14}$} & $\mathrm{CHCl}_{3}$ \\
\hline Dose $(\mathrm{mg} / \mathrm{kg})$ & $\begin{array}{c}\text { Oedema* } \\
(\mathrm{mL} \mathrm{x} \mathrm{h})\end{array}$ & $\begin{array}{c}\text { Inhibition } \\
(\%)\end{array}$ & $\begin{array}{c}\text { Oedema* } \\
(\mathrm{mL} \mathrm{x} \mathrm{h})\end{array}$ & $\begin{array}{c}\text { Inhibition } \\
(\%)\end{array}$ & $\begin{array}{c}\text { Oedema* } \\
(\mathrm{mL} \mathrm{x} \mathrm{h})\end{array}$ & $\begin{array}{c}\text { Inhibition } \\
(\%)\end{array}$ & $\begin{array}{c}\mathrm{Oedema}^{*} \\
(\mathrm{~mL} \times \mathrm{h})\end{array}$ & $\begin{array}{c}\text { Inhibition } \\
(\%)\end{array}$ \\
\hline 0 & $2.81 \pm 0.15$ & - & $2.65 \pm 0.03$ & - & $2.68 \pm 0.05$ & - & $2.45 \pm 0.16$ & - \\
50 & $1.89 \pm 0.13^{\mathrm{b}}$ & 32.7 & $2.13 \pm 0.08^{\mathrm{b}}$ & 19.6 & $2.18 \pm 0.06^{\mathrm{b}}$ & 18.7 & $2.84 \pm 0.08$ & - \\
100 & $1.76 \pm 0.19^{\mathrm{b}}$ & 37.4 & $2.52 \pm 0.10$ & 4.9 & $2.16 \pm 0.07^{\mathrm{b}}$ & 19.4 & $3.11 \pm 0.14$ & - \\
200 & $1.93 \pm 0.08^{\mathrm{b}}$ & 31.3 & $2.51 \pm 0.07$ & 5.3 & $2.34 \pm 0.08^{\mathrm{a}}$ & 12.7 & $2.93 \pm 0.11$ & - \\
ASA & $1.12 \pm 0.08^{\mathrm{b}}$ & 60.1 & $1.77 \pm 0.08^{\mathrm{b}}$ & 33.2 & $1.71 \pm 0.05^{\mathrm{b}}$ & 36.2 & $1.54 \pm 0.11^{\mathrm{b}}$ & 37.1 \\
\hline
\end{tabular}

$\mathrm{n}=6$. Small letters denote statistical significance, ${ }^{\mathrm{a}} p<0.01$ and ${ }^{\mathrm{b}} p<0.001$ in relation to control group. $*$ mean \pm s.e.m.

Table 2. Inhibitory effects of the partitions of Hyptis fruticosa leaves EE on carrageenan-induced leukocyte migration into the peritoneal cavity after $4 \mathrm{~h}$.

\begin{tabular}{|c|c|c|c|c|c|c|c|c|}
\hline \multicolumn{3}{|c|}{$\mathrm{MeOH} / \mathrm{H}_{2} 0$} & \multicolumn{2}{|c|}{ EtOAc } & \multicolumn{2}{|c|}{$n-\mathrm{C}_{6} \mathrm{H}_{14}$} & \multicolumn{2}{|c|}{$\mathrm{CHCl}_{3}$} \\
\hline Dose $(\mathrm{mg} / \mathrm{kg})$ & $\begin{array}{c}\text { Cell x } 10^{6} / \\
\mathrm{mL}^{*}\end{array}$ & $\begin{array}{c}\text { Inhibition } \\
(\%)\end{array}$ & $\begin{array}{c}\text { Cell x } 10^{6} / \\
\mathrm{mL}^{*}\end{array}$ & $\begin{array}{c}\text { Inhibition } \\
(\%)\end{array}$ & $\begin{array}{c}\text { Cell x } 10^{6} \% \\
\mathrm{~mL}^{*}\end{array}$ & $\begin{array}{c}\text { Inhibition } \\
(\%)\end{array}$ & $\begin{array}{c}\text { Cell x } 10^{6} / \\
\mathrm{mL}^{*}\end{array}$ & $\begin{array}{c}\text { Inhibition } \\
(\%)\end{array}$ \\
\hline 0 & $16.3 \pm 1.0$ & - & $13.4 \pm 0.9$ & - & $16.3 \pm 1.0$ & - & $15.8 \pm 0.7$ & - \\
\hline 50 & $10.1 \pm 0.4^{\mathrm{b}}$ & 38.4 & $5.8 \pm 1.1^{\mathrm{b}}$ & 56.9 & $11.6 \pm 0.8^{\mathrm{a}}$ & 28.6 & $18.0 \pm 1.6$ & - \\
\hline 100 & $7.5 \pm 0.8^{b}$ & 54.4 & $5.5 \pm 0.5^{b}$ & 58.9 & $7.4 \pm 0.9^{\mathrm{b}}$ & 54.7 & $11.8 \pm 1.4$ & 24.9 \\
\hline 200 & $7.2 \pm 0.8^{b}$ & 56.0 & $5.9 \pm 1.0^{\mathrm{b}}$ & 55.9 & $5.6 \pm 0.5^{b}$ & 65.4 & $14.4 \pm 0.8$ & 8.6 \\
\hline Dexa & $5.3 \pm 0.3^{b}$ & 67.6 & $4.5 \pm 0.2^{\mathrm{b}}$ & 66.1 & $5.7 \pm 0.3^{b}$ & 64.8 & $6.2 \pm 0.3^{\mathrm{b}}$ & 61.0 \\
\hline
\end{tabular}

$\mathrm{n}=6$. Small letters denote statistical significance, ${ }^{\mathrm{a}} p<0.01$ and ${ }^{\mathrm{b}} p<0.001$ in relation to control group. ${ }^{*}$ mean \pm s.e.m. 
Table 3. IC50 values of $H$. fruticosa leaves EE and its partitions determined by DPPH method.

\begin{tabular}{cc}
\hline Samples & IC50 $(\mu \mathrm{g} / \mathrm{mL} \text { DPPH })^{*}$ \\
\hline EE of leaves & $35.00 \pm 1.01^{\mathrm{ab}}$ \\
$n-\mathrm{C}_{6} \mathrm{H}_{14}$ partition & $78.67 \pm 2.90^{\mathrm{c}}$ \\
$\mathrm{CHCl}_{3}$ partition & $91.33 \pm 2.18^{\mathrm{c}}$ \\
EtOAc partition & $36.67 \pm 2.65^{\mathrm{ab}}$ \\
$\mathrm{MeOH} / \mathrm{H}_{2} \mathrm{O}$ partition & $50.67 \pm 2.29^{\mathrm{b}}$ \\
$(-)-$ Epigallocatechin & $16.67 \pm 1.21^{\mathrm{a}}$ \\
\hline
\end{tabular}

Different small letters means significantly different at $p<0.05$ (triplicate). * IC50 values of extracts $(25 \mu \mathrm{g} / \mathrm{mL})$ were calculated at $50 \mathrm{~min}$.

\section{DISCUSSION}

This study demonstrated that Hyptis fruticosa EE and its $n-\mathrm{C}_{6} \mathrm{H}_{14}$, EtOAc, and $\mathrm{MeOH} / \mathrm{H}_{2} \mathrm{O}$ partitions present inhibitory activities in experimental models of paw oedema and cell migration. In addition, the data presented herein show that the EE and its EtOAc and $\mathrm{MeOH} / \mathrm{H}_{2} \mathrm{O}$ partitions present antioxidant potential.

Initially, we observed that the previous oral treatment with the $\mathrm{EE}$ of $H$. fruticosa leaves or its $n-\mathrm{C}_{6} \mathrm{H}_{14}, \mathrm{EtOAc}$, and $\mathrm{MeOH} / \mathrm{H}_{2} \mathrm{O}$ partitions was effective in reducing the oedematogenic response evoked by carrageenan in rats between the second and fourth hours after the injection. Paw oedema formation is a result of a synergism between inflammatory mediators that increase blood flow and microvascular permeability (Ialenti et al., 1992). The carrageenan-induced rat paw oedema is characterized by an early phase $(1 \mathrm{~h})$ caused by the release of histamine, 5-hydroxytryptamine, and bradykinin followed by a late phase $(2 \mathrm{~h})$ mainly sustained by nitric oxide and prostaglandin release which causes oedema dependent on mobilization of neutrophils (Di Rosa et al., 1971; Salvemini et al., 1996).

To gain further insight into the anti-inflammatory effect induced by EE of $H$. fruticosa, we evaluated its effect in other experimental model of inflammation. Cell recruitment during inflammation depends on the orchestrated release of local mediators which are responsible for local vascular and tissue changes as well as for the recruitment of host defense cells (Luster et al., 2005). The leukocyte migration induced by i.p. injection of carrageenan involves many mediators, including eicosanoids, cytokines, and chemokines (Ogino et al., 1996; Fröde et al., 2001). The EE and its $n-\mathrm{C}_{6} \mathrm{H}_{14}$, EtOAc, and $\mathrm{MeOH} / \mathrm{H}_{2} \mathrm{O}$ partitions inhibited leukocyte migration induced by i.p. injection of carrageenan (in peritonitis model).

Previous study has demonstrated that the aqueous leaves extract of $H$. pectinata and several extracts of Hyptis verticillata shown anti-inflammatory activity (Kuhnt et al., 1995; Bispo et al., 2001). In

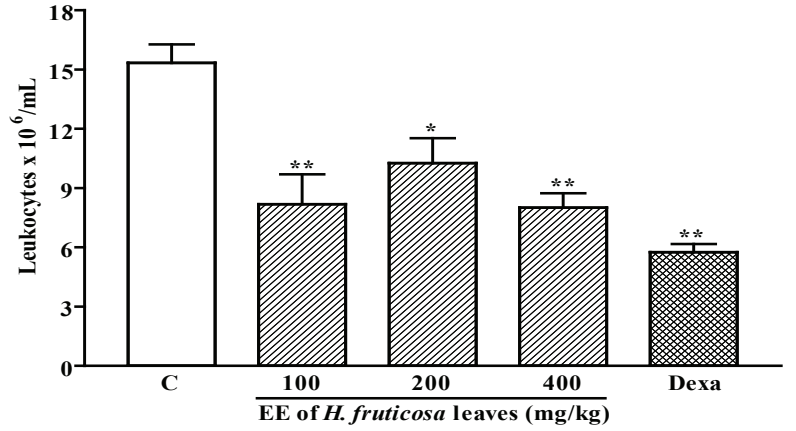

Figure 2. Effect of Hyptis fruticosa leaves EE on leukocyte migration. Rats were pre-treated with vehicle (C, p.o.), dexamethasone (Dexa, $2 \mathrm{mg} / \mathrm{kg}$, s.c.), or EE (100-400 mg/kg, p.o. $) 1 \mathrm{~h}$ before carrageenan $(500 \mu \mathrm{g}$, i.p. $)$. Cell counts were performed at the time $4 \mathrm{~h}$ after the carrageenan. Each value represents the mean \pm s.e.m. ${ }^{*} p<0.05$ and ${ }^{* *} p<0.001$, in relation to control group. ANOVA followed by Tukey's test ( $n=6 /$ group).

fact, various species of the family Lamiaceae has been reported to contain anti-inflammatory activity, e.g. Plectranthus amboinicus, Clinopodium vulgare, and Lamium garganicum (Akkol et al., 2008; Burk et al., 2009; Gurgel et al., 2009). The present study shown that $H$. fruticosa markedly inhibited the local and acute manifestations in experimental models of inflammation. A putative mechanism associated with this activity may be inhibition of the synthesis of many inflammatory mediators whose involvement in the oedema and cell migration is well-established. However, these possibilities remains to be tested in future studies.

The antioxidant capacity of many substances confers a therapeutic potential with anti-inflammatory property (Li et al., 2002; Librowski et al., 2005). In our work demonstrated that the $\mathrm{EE}$ and EtOAc partition have highest antioxidant potential, and the $\mathrm{MeOH} / \mathrm{H}_{2} \mathrm{O}$ partition has moderate antioxidant potential. However, the $n-\mathrm{C}_{6} \mathrm{H}_{14}$ and $\mathrm{CHCl}_{3}$ partitions are poor sources of antioxidants. Some studies have demonstrated that the extracts of Hyptis fasciculate shown to be active as DPPH radical scavengers (Silva et al., 2005, 2009) and others Lamiaceae plants (e.g. some Salvia species, Gontscharovia popovii) represent good potential sources of natural antioxidants useful for either prevention or treatment of oxidative stress-related diseases (Firuzi et al., 2010).

The phytochemical study of $H$. fruticosa leaves detected large amounts of phenolic compounds in the $\mathrm{EE}$, as well as, EtOAc and $\mathrm{MeOH} / \mathrm{H}_{2} \mathrm{O}$ partitions. Xanthones, a widespread polyphenolic compound in plants, have extensive pharmacological activities such as antioxidant, antihypertensive, inhibition of platelet aggregation, antiulcer, and anti-inflammatory (Peres et al., 2000; Librowski et al., 2005). Flavonoids are the major secondary metabolites class with several descriptions of antioxidant property which confers a therapeutic potential with anti-inflammatory effect (Rajendran et al., 2000; Li et al., 2002; Matsuda et al., 2003). Flavonoids have been 
shown to inhibit the inducible isoforms of cyclo-oxygenase (COX-2) and nitric oxide synthase (iNOS), lipooxygenase, microsomal monooxygenase, glutathione S-transferase, and nicotinamide adenine dinucleotide phosphate (NADPH)-oxidase, all involved in reactive oxygen species generation (Odontuya et al., 2005; Soobrattee et al., 2005). Others anti-inflammatory properties of flavonoids are their suggested ability to inhibit neutrophil degranulation and reduce complement activation, thereby decreasing the adhesion of inflammatory cells to the endothelium (Nijveldt et al., 2001). It has been demonstrated that tannins are also able to inhibit COX-2 and/or iNOS enzymes, as well as other mediators of the inflammatory process (Carvalho, 2004). A number of saponins have been previously reported to have anti-inflammatory effects. For example, soybean saponins were reported to suppress the release of proinflammatory mediators by peritoneal macrophages, saponins from Platycodon grandiflorum were reported to inhibit expression of iNOS and COX-2, and ginsenosides were reported to inhibit COX-2 expression (Ahn et al., 2005; Kang et al., 2005; Lee et al., 2005). These previous studies confirm our dates in this work that demonstrated the presence of flavonoids, saponins, tannins, and xanthones in the $\mathrm{EE}$, and $\mathrm{EtOAc}$ and $\mathrm{MeOH} / \mathrm{H}_{2} \mathrm{O}$ partitions with antiinflammatory and antioxidant effects.

In addition, steroids have been reported as potent anti-inflammatory agents (Mencarelli et al., 2009). In our work demonstrated that the $n-\mathrm{C}_{6} \mathrm{H}_{14}$ partition contains steroids and its shows anti-inflammatory activity and poor antioxidant action. The $\mathrm{CHCl}_{3}$ partition did not show antiinflammatory and antioxidant activities, which is destitute of flavonoids, saponins, tannins, xanthones, and steroids.

In conclusion, $H$. fruticosa shows antiinflammatory and antioxidant activities. The identification and isolation of such bioactive components are in progress, which could elucidate the anti-inflammatory property of this plant.

\section{ACKNOWLEDGEMENTS}

This study was supported by Conselho Nacional de Desenvolvimento Científico e Tecnológico (CNPq $\mathrm{PIBIC} / \mathrm{CNPq} / \mathrm{UFS})$.

\section{REFERENCES}

Ahn KS, Noh EJ, Zhao HL, Jung SH, Kang SS, Kim YS 2005. Inhibition of inducible nitric oxide synthase and cyclooxygenase II by Platycodon grandiflorum saponins via suppression of nuclear factor-kappaB activation in RAW 264.7 cells. Life Sci 76: 2315-2328.

Akkol EK, Yalçin FN, Kaya D, Caliş I, Yesilada E, Ersöz T 2008. In vivo anti-inflammatory and antinociceptive actions of some Lamium species. J Ethnopharmacol 118: 166-172.

Akah PA, Nwambie AI 1993. Nigerian plants with anti-convulsant property. Fitoterapia 64: 42-44.

Arrigoni-Blank MF, Antoniolli AR, Caetano LC, Campos DA, Blank AF, Alves PB 2008. Antinociceptive activity of the volatile oils of Hyptis pectinata L. Poit. (Lamiaceae) genotypes. Phytomedicine 15: 334-339.

Barbosa PPP, Ramos CP 1992. Studies on the antiulcerogenic activity of the essential oil of Hyptis mutabilis Briq in rats. Phytother Res 6: 114-115.

Bispo MD, Mourão RH, Franzotti EM, Bomfim KB, ArrigoniBlank MF, Moreno MP, Marchioro M, Antoniolli AR 2001. Antinociceptive and antiedematogenic effects of the aqueous extract of Hyptis pectinata leaves in experimental animals. $J$ Ethnopharmacol 76: 81-86.

Burk DR, Senechal-Willis P, Lopez LC, Hogue BG, Daskalova SM 2009. Suppression of lipopolysaccharide-induced inflammatory responses in RAW 264.7 murine macrophages by aqueous extract of Clinopodium vulgare L. (Lamiaceae). J Ethnopharmacol 126: 397-405.

Brand-Williams W, Cuvelier ME, Berset C 1995. Use of a free radical method to evaluate antioxidant activity. Lebensmittel Wissenschaft Technologie 28: 25-30.

Calixto JB 2005. Twenty-five years of research on medicinal plants in Latin America: a personal view. J Ethnopharmacol 100: 131-134.

Carvalho JCT 2004. Fitoterápicos antiinflamatórios: aspectos químicos, farmacológicos e aplicações terapêuticas. Ribeirão Preto: Tecmedd Editora.

Di Rosa M, Giroud JP, Willoughby DA 1971. Studies on the mediators of the acute inflammatory response induced in rats in different site by carrageenan and terpentine. $J$ Pathol 104: 15-21.

Esquenazi D, Wigg MD, Miranda MMFS, Rodrigues HM, Tostes JBF, Rozental S, Silva AJR, Alviano CS 2002. Antimicrobial and antiviral activities of polyphenolics from Cocos nucifera Linn (Palmae) husk fiber extract. Res Microbiol 153: 647-652.

Firuzi O, Javidnia K, Gholami M, Soltani M, Miri R 2010. Antioxidant activity and total phenolic content of 24 Lamiaceae species growing in Iran. Nat Prod Commun 5: 261-264.

Fröde TS, Souza GE, Calixto JB 2001. The modulatory role played by TNF-alpha and IL-1 beta in the inflammatory responses induced by carrageenan in the mouse model of pleurisy. Cytokine 13: 162-168.

Gurgel AP, da Silva JG, Grangeiro AR, Oliveira DC, Lima CM, da Silva AC, Oliveira RA, Souza IA 2009. In vivo study of the anti-inflammatory and antitumor activities of leaves from Plectranthus amboinicus (Lour.) Spreng (Lamiaceae). J Ethnopharmacol 125: 361-363.

Harbone JB 1984. Phytochemical Methods. In: A Guide to Modern Techniques of Plant Analysis. London: Chapman and Hall, p. 324.

Harley RM 1988. Revision of generic limits in Hyptis Jacq (Labiatae) and its allies. Bot J Linn Soc 98: 87-95.

Ialenti A, Ianaro A, Moncada S, Di Rosa M 1992. Modulation of acute inflammation by endogenous nitric oxide. Eur $J$ Pharmacol 211: 177-182.

Kang JH, Sung MK, Kawada T, Yoo H, Kim YK, Kim JS, Yu $R$ 2005. Soybean saponins suppress the release of proinflammatory mediators by LPS-stimulated peritoneal macrophages. Cancer Lett 230: 219-227.

Kuhnt M, Probstle A, Rimpler H, Bauer R, Heinrich M 1995. Biological and pharmacological activities and further constituents of Hyptis verticillata. Planta Med 61: 227232.

Lee JY, Shin JW, Chun KS, Park KK, Chung WY, Bang 
YJ 2005. Anti-tumor promotional effects of a novel intestinal bacterial metabolite (IH-901) derived from the protopanaxadiol type ginsenosides in mouse skin. Carcinogenesis 26: 359-367.

Li DW, Lee EB, Kang SS, Hyun JE, Whang WK 2002. Activity guided isolation of saponins from Kalopanax pictus with anti-inflammatory activity. Chem Pharm Bull 50: 900903.

Librowski T, Czarnecki R, Czekaj T, Marona H 2005. New xanthone derivatives as potent anti-inflammatory agents. Medicina (Kaunas) 41: 54-58.

Luster AD, Alon R, von Andrian UH 2005. Immune cell migration in inflammation: present and future therapeutic targets. Nat Immunol 6: 1182-1190.

Matsuda H, Morikawa T, Ando S, Toguchida I, Yoshikawa M 2003. Structural requirements of flavonoids for nitric oxide production inhibitory activity and mechanism of action. Bioorg Med Chem 11: 1995-2000.

Mencarelli A, Renga B, Palladino G, Distrutti E, Fiorucci S 2009. The plant sterol guggulsterone attenuates inflammation and immune dysfunction in murine models of inflammatory bowel disease. Biochem Pharmacol 78: 1214-1223.

Menezes IA, Marques MS, Santos TC, Dias KS, Silva AB, Mello IC, Lisboa AC, Alves PB, Cavalcanti SC, Marcal RM, Antoniolli AR 2007. Antinociceptive effect and acute toxicity of the essential oil of Hyptis fruticosa in mice. Fitoterapia 78: 192-195.

Nijveldt RJ, Van-Nood E, Van-Hoorn DEC, Boelens PG, VanNorren K, Van-Leeuwer PAM 2001. Flavonoids: a review of probable mechanisms of action and potential applications. Am J Clin Nutr 74: 418-425.

Odontuya G, Hoult JRS, Houghton PJ 2005. Structure-activity relationship for anti-inflammatory effect of luteolin and its derived glycosides. Phytother Res 19: 782-786.

Ogino M, Majima M, Kawamura M, Hatanaka K, Saito M, Harada Y, Katori M 1996. Increased migration of neutrophils to granulocyte-colony stimulating factor in rat carrageenininduced pleurisy: roles of complement, bradykinin, and inducible cyclooxygenase-2. Inflamm Res 45: 335-346.

Peres V, Nagem TJ, De Oliveira FF 2000. Tetraoxygenated naturally occurring xanthones. Phytochemistry 55: 683710.

Rajendran NN, Thirugnanasambandam P, Viswanathan S, Parvathi V, Ramasamy S 2000. Antinociceptine pattern of flavone and its mechanism as tested by formalin assay. Indian J Exp Biol 38: 182-185.

Salvemini D, Wang ZQ, Wyatt PS, Bourdon DM, Marino MH, Manning PT, Currie MG 1996. Nitric oxide: a key mediator in the early and late phase of carrageenaninduced rat paw inflammation. Brit J Pharmacol 118: 829-838.

Santos MR, Carvalho AA, Medeiros IA, Alves PB, Marchioro M, Antoniolli AR 2007. Cardiovascular effects of Hyptis fruticosa essential oil in rats. Fitoterapia 78: 186-191.

Silva ABL, Dias KS, Marques MS, Menezes IAC, Santos TC, Mello ICM, Lisboa ACCD, Cavalcanti SCH, Marçal RM, Antoniolli AR 2006. Avaliação do efeito antinociceptivo e da toxicidade aguda do extrato aquoso da Hyptis fruticosa Salmz. ex Benth. Rev Bras Farmacogn 16: 475-479.

Silva CG, Herdeiro RS, Mathias CJ, Panek AD, Silveira CS, Rodrigues VP, Rennó MN, Falcão DQ, Cerqueira DM,
Minto ABM, Nogueira FLP, Quaresma CH, Silva JFM, Menezes FS, Eleutherio ECA 2005. Evaluation of antioxidant activity of Brazilian plants. Pharmacol Res 52: 229-233.

Silva CG, Raulino RJ, Cerqueira DM, Mannarino SC, Pereira MD, Panek AD, Silva JFM, Menezes FS, Eleutherio ECA 2009. In vitro and in vivo determination of antioxidant activity and mode of action of isoquercitrin and Hyptis fasciculata. Phytomedicine 16: 761-767.

Soobrattee MA, Neergheen VS, Luximon-Ramma A, Aruoma OI, Bahorun T 2005. Phenolics as potential antioxidant therapeutic agents: mechanism and actions. Mutat Res 579: 200-213.

Thomazzi SM, Silva CB, Silveira DCR, Vasconcellos CLC, Lira AF, Cambuí EVF, Estevam CS, Antoniolli AR 2010. Antinociceptive and anti-inflammatory activities of Bowdichia virgilioides (sucupira). J Ethnopharmacol 127: 451-456.

Winter CA, Risley EA, Nuss GW 1962. Carrageenin-induced edema in hind paw of the rat as an assay for antiinflammatory drugs. Proc Soc Exp Biol Med 111: 544547. 